\title{
Regulation of osteoprotegerin production by androgens and anti-androgens in human osteoblastic lineage cells
}

\author{
Lorenz C Hofbauer, Kevin C Hicok ${ }^{1}$, David Chen $^{2}$ and Sundeep Khosla ${ }^{1}$ \\ Division of Endocrinology, Philipps University, Marburg, Germany, ${ }^{1}$ Endocrine Research Unit, Mayo Clinic, Rochester, Minneapolis, USA and ${ }^{2}$ Amgen \\ Inc., Thousand Oaks, California, USA
}

(Correspondence should be addressed to L C Hofbauer, Division of Gastroenterology, Endocrinology and Metabolism, Department of Medicine, Philipps University, Baldingerstrasse, D-35033 Marburg, Germany; Email: hofbauer@post.med.uni-marburg.de)

\begin{abstract}
Background: Estrogens and androgens have anti-resorptive effects on bone, although recent evidence indicates that, even in men, estrogen is the dominant sex steroid regulating bone resorption. The receptor activator of NF- $\mathrm{BB}$ ligand is essential for osteoclastic bone resorption, and its effects are blocked by the decoy receptor, osteoprotegerin (OPG). While estrogen has been shown to induce osteoblastic OPG production, the effects of androgens on OPG production have not been defined.

Methods: In this study, we assessed the regulation of OPG by androgens in hFOB/AR-6, an immortalized fetal osteoblastic cell line stably transfected with the human androgen receptor (AR), and MSC cells, primary human pluripotent marrow stromal cells capable of differentiating towards mature osteoblasts.

Results and Conclusions: $5 \alpha$-Dihydrotestosterone (DHT) dose-dependently decreased OPG mRNA levels and protein concentrations in hFOB/AR- 6 cells by up to 50 and $60 \%$ respectively $(P<0.001)$. Inhibition of OPG mRNA levels and protein production by $5 \alpha$-DHT was completely abrogated by the AR antagonist, hydroxyflutamide (OHF), indicating that these effects are directly mediated by the AR. Of note, OHF alone increased OPG mRNA levels and protein secretion by 2- to 3-fold. Moreover, $5 \alpha$-DHT and testosterone also decreased OPG protein secretion by $40-46 \%$ in the untransformed MSC cells, while OHF stimulated it. In conclusion, we demonstrate that androgens specifically inhibit OPG mRNA levels and protein secretion by osteoblastic cells.
\end{abstract}

European Journal of Endocrinology 147 269-273

\section{Introduction}

Androgens and estrogens have been shown to inhibit bone resorption in vitro via direct effects on osteoclasts $(1,2)$ as well as through inhibition of the production of the pro-resorptive cytokine, interleukin (IL)-6 (3-6). However, both estrogen receptor- and aromatasedeficient males have elevated indices of bone resorption despite normal or elevated testosterone levels $(7,8)$, suggesting that even in men, estrogen is the critical sex steroid regulating bone resorption. Consistent with this, a recent clinical investigative study in normal elderly males found that, at physiological levels, estrogen was the dominant sex steroid regulating bone resorption in vivo (9). These findings suggest that the effects of androgens and estrogens on bone metabolism may not be interchangeable, due perhaps to the differential regulation of certain key cytokines regulating bone resorption.

Recently, the receptor activator of NF-кB ligand (RANKL), a novel member of the tumor necrosis factor ligand family, has been shown to stimulate differentiation, activation and survival of osteoclasts (10). RANKL is produced by osteoblastic lineage cells and activated T lymphocytes, and stimulates its receptor, RANK, located on the surface of osteoclastic lineage cells $(10,11)$. The effects of RANKL are blocked by the receptor antagonist osteoprotegerin (OPG), which is secreted by various cell types, including osteoblastic lineage cells (12). Osteoclast differentiation, survival and activation are stimulated by RANKL and blocked by OPG (13). The production of RANKL and OPG within the bone microenvironment is modulated by various hormones and cytokines and is altered in several metabolic bone diseases (13). RANKL and OPG constitute an obvious cytokine system to mediate the anti-resorptive effects of sex steroid hormones. Two studies have recently demonstrated that $17 \beta$-estradiol stimulates OPG production in estrogen-responsive osteoblastic lineage cells $(14,15)$. However, the possible effects of androgens on OPG production by osteoblasts have not been evaluated. In this study, we assessed 
the effects of androgens on OPG production by an immortalized human osteoblastic cell line stably transfected with androgen receptor (AR) cDNA (hFOB/AR-6) (16) and primary human pluripotent marrow stromal cells (MSC) (17).

\section{Materials and methods}

\section{Reagents}

Culture flasks and dishes were obtained from Corning (Corning, NY, USA). Cell culture medium, supplements and androgens were purchased from Sigma Chemical Co. (St Louis, MO, USA). Fetal bovine serum (FBS) was from GIBCO-BRL (Grand Island, NY, USA). Hygromycin B was purchased from Flow-ICN (Costa Mesa, CA, USA). Hydroxyflutamide (OHF), a non-steroidal anti-androgen, was kindly provided by Dr Rudolph Neri (Schering-Plough, Klenisworth, NJ, USA). The random primer labeling kit (Decaprime II) was from Ambion (Austin, TX, USA) and $\left[\alpha-{ }^{32} \mathrm{P}\right] \mathrm{dCTP}$ was from DuPont-NEN (Boston, MA, USA). Hybond $\mathrm{N}^{+}$nylon membranes were from Amersham (Arlington Heights, IL, USA). The human $\beta$-actin cDNA insert and ExpressHyb solution were purchased from Clontech (Palo Alto, CA, USA). Unless otherwise noted, all other reagents were purchased from Sigma.

\section{Cell culture}

The hFOB cell line was developed by conditionally immortalizing human fetal osteoblasts with a temperature-sensitive mutant of the SV40 large T antigen (ts-SV40LTA) gene (18). At $33.5^{\circ} \mathrm{C}$, the ts-SV40LTA is active and the hFOB cells proliferate rapidly, whereas at $39.5^{\circ} \mathrm{C}$, the ts-SV40LTA is inactive and the cells differentiate and display the phenotype of mature osteoblasts. The hFOB/AR-6 cell line was derived by stably transfecting the hFOB cells with an expression vector containing the human wild-type AR cDNA (16). The hFOB/AR-6 cell line expresses osteoblastic differentiation markers, including alkaline phosphatase, osteocalcin, and type I collagen, and is capable of forming mineralized nodules under appropriate conditions. The hFOB/AR-6 cells were maintained in a 1:1 mixture of DMEM/Ham F12 containing 10\% charcoal-stripped FBS and either geneticin $(300 \mu \mathrm{g} / \mathrm{ml})$ or hygromycin B $(100 \mu \mathrm{g} / \mathrm{ml})$. The cells were incubated with serumfree medium supplemented with $0.125 \%(\mathrm{w} / \mathrm{v}) \mathrm{BSA}$ and either vehicle or test agent for the time indicated. The conditioned medium was collected and centrifuged at $4000 \mathrm{~g}$ for $4 \mathrm{~min}$ at $4{ }^{\circ} \mathrm{C}$ to remove cell debris, and was stored at $-80^{\circ} \mathrm{C}$ until used for analysis.

MSC cells were purchased from Osiris (Baltimore, MD, USA) and were cultured in osteogenesis-induction medium containing $0.1 \mu \mathrm{mol} / \mathrm{l}$ dexamethasone, $0.05 \mathrm{mmol} / \mathrm{l}$ ascorbic acid-2-phosphate, and $10 \mathrm{mmol} / \mathrm{l}$ $\beta$-glycerol phosphate for 14 days (17). The transformed murine stromal cell line ST-2 was maintained in $\alpha$-MEM medium supplemented with $10 \%$ fetal calf serum and $1 \%$ penicillin and streptomycin. Treatment with androgens at varying concentrations or ethanol was performed in the presence of $1 \%$ fetal calf serum for the time indicated.

\section{Semiquantitative RT-PCR}

Total RNA was isolated from ST-2 cells using the RNeasy kit from Qiagen (Hilden, Germany). Reverse transcription (in triplicates) was performed with $1 \mu \mathrm{g}$ total RNA as previously described (19) and the PCR products were analyzed by electrophoresis on a 1.5\% $(\mathrm{w} / \mathrm{v})$ agarose gel and visualized under UV light. Gel slices of radiolabeled PCR products were prepared from the gel and the radioactivity was determined in a liquid scintillation counter (19).

\section{Northern blot hybridization}

Ten micrograms of total RNA were separated on a formaldehyde-containing agarose gel and then transferred to a nylon membrane (Hybond $\mathrm{N}+$ ) by capillary blotting. Methylene blue staining of the membrane was used to verify equal loading and efficient transfer. The human cDNA inserts ( $25 \mathrm{ng}$ ), an OPG cDNA that hybridized to a $2.9 \mathrm{~kb}$ mRNA and a $\beta$-actin $\mathrm{cDNA}$ that hybridized to a $2.0 \mathrm{~kb}$ mRNA were radiolabeled with $5 \mu \mathrm{l}$ $\left[\alpha-{ }^{32} \mathrm{P}\right] \mathrm{dCTP}$ to a specific activity of $10^{9}$ c.p.m./ $\mu \mathrm{g}$ DNA using random primer labeling (19). Hybridization and stringent washing were carried out as reported elsewhere (19), and the membranes were subjected to autoradiography at $-80^{\circ} \mathrm{C}$. Control hybridization with human $\beta$-actin cDNA verified that equal amounts of RNA were loaded. All experiments were carried out at least three times, and band intensity was quantified by densitometry.

\section{OPG protein measurement}

OPG protein concentrations were measured in triplicates using a sandwich ELISA as described previously (19). OPG levels were corrected for total RNA to adjust for variations in cell number and are expressed as percent of control.

\section{Statistical analysis}

All numerical values are expressed as the mean \pm S.E.M. A two-tailed Student's paired t-test was used to evaluate differences between the sample of interest and its respective control. In dose-response experiments, we employed ANOVA followed by a Fisher least significant difference test as a multiple-comparison test. A $P$ value of less than 0.05 was considered significant. 


\section{Results}

\section{Regulation of OPG production by androgens and anti-androgens in human fetal osteoblastic lineage cells stably transfected with the AR (hFOB/AR-6)}

Because the hFOB/AR- 6 cells produced 8- to 10-fold higher OPG mRNA levels and protein concentrations at the restrictive temperature $\left(39.5^{\circ} \mathrm{C}\right)$, all studies were performed at $39.5^{\circ} \mathrm{C}$ to allow for osteoblastic differentiation. $\quad 5 \alpha$-Dihydrotestosterone $\quad(5 \alpha$-DHT) decreased OPG mRNA steady state levels in a dosedependent fashion by $50 \%$ at a concentration of $10^{-7} \mathrm{~mol} / \mathrm{l}$ (Fig. 1A). $5 \alpha$-DHT also induced a similar inhibition of OPG protein secretion by hFOB/AR-6

A

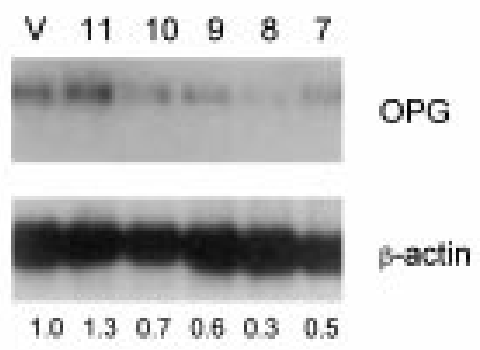

B

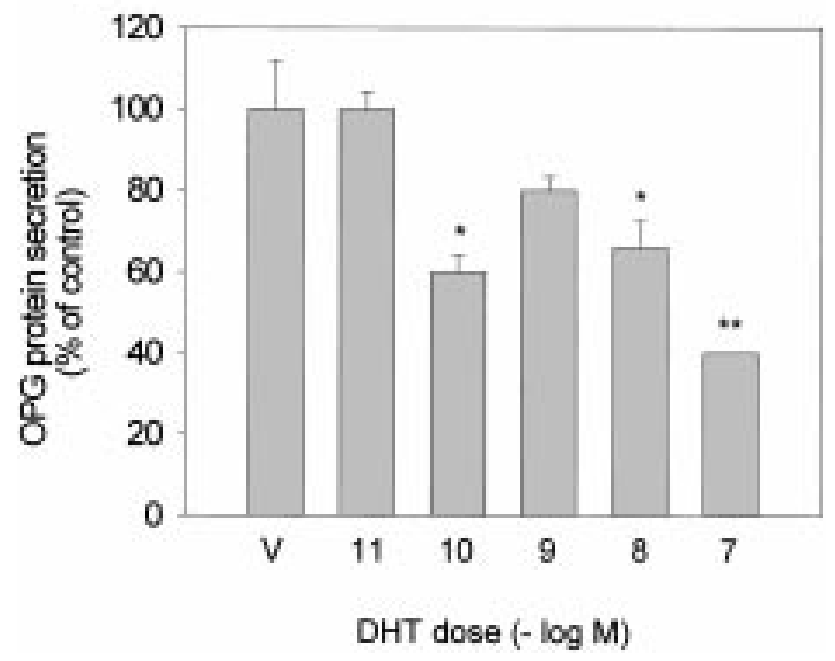

Figure 1 Inhibition of osteoprotegerin (OPG) mRNA levels and protein secretion by $5 \alpha$-dihydrotestosterone (DHT) in hFOB/AR- 6 cells. (A) Northern analysis using $10 \mu \mathrm{g}$ total RNA harvested from hFOB/AR- 6 cells treated for $24 \mathrm{~h}$ at $39.5^{\circ} \mathrm{C}$ with either vehicle (V) or different concentrations of $5 \alpha-\mathrm{DHT}$. The numbers above indicate the concentrations $(-\log \mathrm{mol} / \mathrm{l})$, the numbers below represent OPG/ $\beta$-actin ratios determined by densitometry and normalized to the control (1.0). (B) OPG protein assay using conditioned medium from hFOB/AR- 6 cells treated as described in $(A)$. Values represent the means \pm S.E.M. of triplicate measurements. $P<0.001$ by ANOVA, ${ }^{\star} P<0.01$ and ${ }^{* \star} P<0.005$ by the Fisher least significant differences test with respect to the vehicle control. cells (by $60 \%$ at a concentration of $10^{-7} \mathrm{~mol} / \mathrm{l}$ ) (Fig. 1B). Co-treatment with the specific AR antagonist OHF $\left(10^{-6} \mathrm{~mol} / \mathrm{l}\right)$ completely prevented $5 \alpha$-DHTinduced inhibition of OPG mRNA levels and protein production, indicating that the inhibition by $5 \alpha$-DHT is directly and specifically mediated through the AR (Fig. 2A and B). Of note, OHF alone increased OPG protein secretion (Fig. 2B), and further analysis demonstrated a dose-dependent enhancement of OPG protein secretion by OHF (data not shown). RANKL mRNA was not consistently expressed by hFOB/AR-6 as assessed by RT-PCR, and when detected, was not regulated by either $5 \alpha$-DHT or OHF.
A
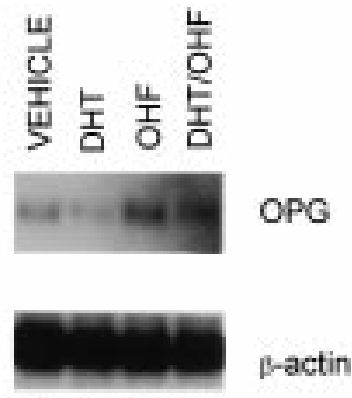

$1.0 \quad 0.52 .1 \quad 1.4$

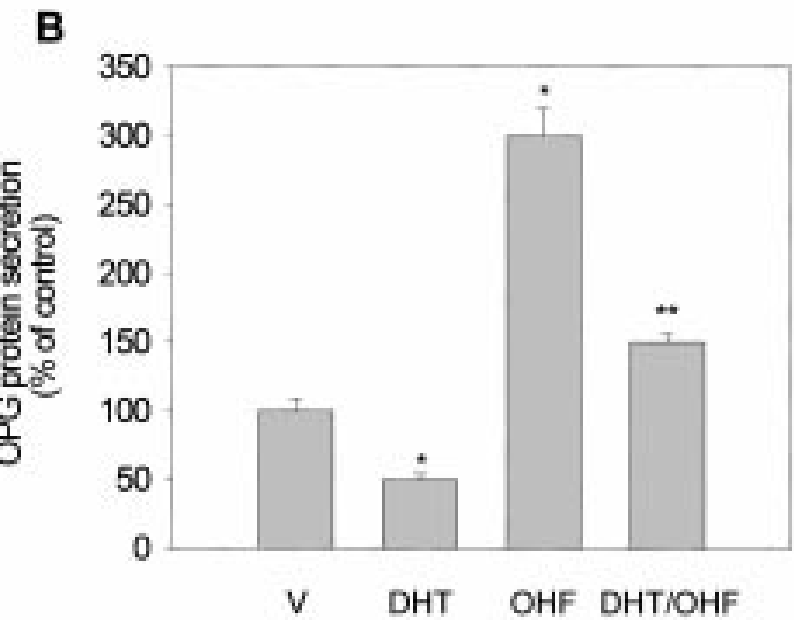

Figure 2 Effects of the androgen receptor antagonist hydroxyflutamide (OHF) on $5 \alpha$-DHT-induced inhibition of OPG mRNA and protein production. (A) Northern analysis using $10 \mu \mathrm{g}$ total RNA isolated from $\mathrm{hFOB} / \mathrm{AR}-6$ cells treated for $24 \mathrm{~h}$ at $39.5^{\circ} \mathrm{C}$ with vehicle (V), $5 \alpha-\mathrm{DHT}\left(10^{-7} \mathrm{~mol} / \mathrm{l}\right)$, OHF $\left(10^{-6} \mathrm{~mol} / \mathrm{l}\right)$, or both. The numbers below represent $O P G / \beta$-actin ratios determined by densitometry and normalized to the control (1.0). (B) OPG protein assay using conditioned medium harvested from hFOB/AR- 6 cells treated as described in (A). Values represent the means \pm S.E.M. from triplicate measurements. ${ }^{*} P<0.01$ by Student's $t$-test vs vehicle, ${ }^{* *} P<0.05$ by Student's $t$-test vs $5 \alpha$-DHT alone. 


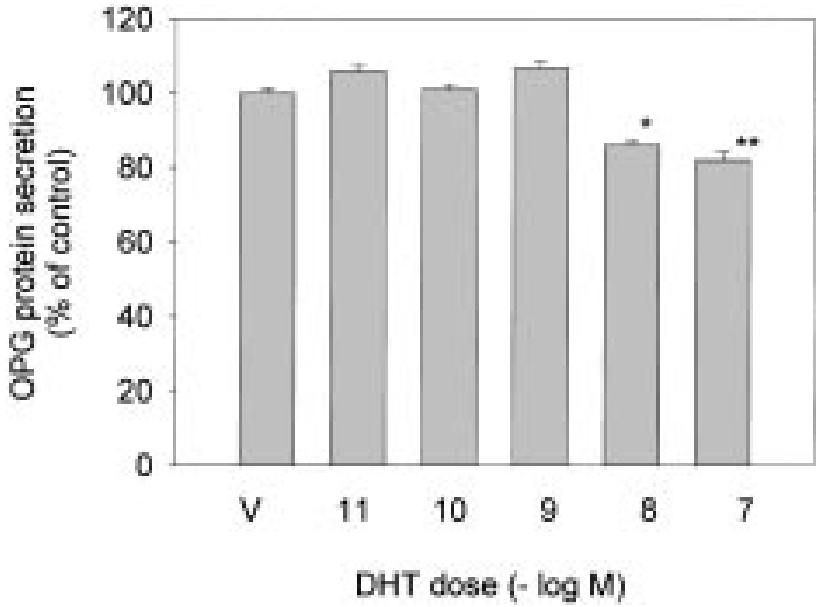

Figure 3 Dose-dependent inhibition of OPG protein secretion by $5 \alpha$-DHT in marrow stromal cells (MSC). The MSC cells were cultured at $37^{\circ} \mathrm{C}$ for $24 \mathrm{~h}$ in the presence of vehicle $(\mathrm{V})$ or different concentrations of $5 \alpha-\mathrm{DHT}$. $P<0.005$ by ANOVA, ${ }^{*} P<0.05$ and ${ }^{* *} P<0.01$ by the Fisher least significant differences test with respect to the vehicle control. The numbers indicate the concentration $(-\log \mathrm{mol} / \mathrm{l})$. OPG concentrations were determined by ELISA and the values represent means \pm S.E.M. from triplicate measurements expressed as percentage of controls.

\section{Regulation of OPG production by androgens and anti-androgens in MSC non-transfected bone marrow stromal cells}

To confirm that the inhibition of OPG production by androgens was not limited to the conditionally immortalized transformed cell line that had been transfected with the AR (hFOB/AR-6), we used the MSC cells. The inhibition of OPG protein production by MSC cells after treatment with $5 \alpha$-DHT was dose-dependent with a maximal effect at a concentration of $10^{-7} \mathrm{~mol} / \mathrm{l}$ for $24 \mathrm{~h}$ (Fig. 3). Equimolar concentrations of testosterone also decreased OPG protein secretion by MSC cells to a similar extent, suggesting that the MSC cells express the enzyme $5 \alpha$-reductase, the enzyme that converts testosterone to $5 \alpha$-DHT.

In order to assess whether the inhibitory effects of androgens were limited to human osteoblastic lineage cells, we also employed the murine stromal cell line, ST-2. $5 \alpha$-DHT dose-dependently inhibited OPG mRNA expression by ST- 2 cells as assessed by semiquantitative RT-PCR by up to $37 \%$ with a maximum effect at a concentration of $10^{-8} \mathrm{~mol} / \mathrm{l}$ for $24 \mathrm{~h}(P<0.01)$. In the MSC cells, OHF dose-dependently enhanced OPG protein secretion (Table 1), and was capable of partially reversing the inhibitory effects of $5 \alpha$-DHT on OPG protein secretion (data not shown).

\section{Discussion}

There is emerging evidence that RANKL and OPG are critical osteoblast-derived determinants of osteoclast
Table 1 Stimulation of OPG protein secretion by OHF in human primary untransformed adult marrow stromal cells (MSC). The MSC cells were cultured at $37^{\circ} \mathrm{C}$ for $24 \mathrm{~h}$ in the presence of vehicle or different concentrations of OHF. The numbers indicate the concentration ( $-\log \mathrm{mol} / \mathrm{l})$. OPG concentrations were determined by ELISA and the values represent the means \pm S.E.M. from triplicate measurements normalized to the control (\%). $P<0.005$ by ANOVA, $P$ values for Fisher least significant differences test are included.

\begin{tabular}{ll}
\hline Concentration $(\mathrm{mol} / \mathrm{l})$ & \multicolumn{1}{c}{ Response $(\%)$} \\
\hline Vehicle & $100 \pm 0.95$ \\
$10^{-9}$ & $108 \pm 0.68(P<0.005)$ \\
$10^{-8}$ & $124 \pm 5.73(P<0.01)$ \\
$10^{-7}$ & $113 \pm 2.52(P<0.01)$ \\
$10^{-6}$ & $114 \pm 4.97(P<0.05)$ \\
$10^{-6}$ & $120 \pm 0.80(P<0.001)$ \\
\hline
\end{tabular}

biology and bone resorption (13). Many factors known to affect bone resorption have been demonstrated to operate through altered RANKL and OPG production (13). In the present study, we show that the non-aromatizable androgen, $5 \alpha$-DHT, inhibits OPG production by mature osteoblastic cells (hFOB/AR-6) in a dose-dependent manner, at the mRNA and protein level, and through a specific activation of the AR. Moreover, a similar inhibition of OPG of smaller magnitude was also observed in the MSC cells, likely reflecting their lower number of ARs. Thus, inhibition of OPG was present in both a transformed and a non-transformed human cell system. Finally, androgens also decreased OPG mRNA production by the murine stromal cell line (ST-2), indicating that inhibition of OPG by androgen is not speciesspecific. Together, these data indicate that inhibition of osteoblastic OPG production by androgens fulfills the criteria for a physiological response. RANKL mRNA was not consistently detected in the hFOB/AR-6 and MSC cells and not regulated by androgens, indicating that the effects of androgens on the RANKL/OPG system may be mainly mediated through modulation of OPG production.

The inhibitory effects of androgens on OPG production by osteoblastic lineage cells are opposite to those of estrogens $(14,15)$. This is in contrast to another bone-resorbing osteoblast-derived cytokine, IL-6, which is inhibited by androgens and estrogens (3-6). In addition, androgens and estrogens have been shown to have direct inhibitory effects on osteoclasts $(1,2)$. Thus, the opposite regulation of the potent anti-resorptive cytokine, OPG, by androgens vs estrogens provides a possible mechanism for the clinical observations that androgens have weaker anti-resorptive effects than estrogen in vivo (7-9). Consistent with this, we have recently found that under conditions in which elderly men are rendered acutely hypogonadal and then replaced with estrogen alone, testosterone 
alone, or both, estrogen and testosterone also have opposite effects on circulating OPG levels in vivo (20). Moreover, serum OPG levels are higher in women compared with men (21). Thus, these in vitro and in vivo data suggest that estrogens and androgens regulate osteoblastic OPG production in opposite directions, and that the anti-resorptive effects of androgens may be mediated independently of the RANKL/OPG system.

Our findings that the pure AR antagonist, OHF, stimulates OPG mRNA levels and protein secretion by the hFOB/AR-6 cell line suggest that it may have positive effects on bone metabolism. In support of this are our previous results demonstrating that $\mathrm{OHF}$ also inhibits IL- 6 gene expression and protein production by the hFOB/AR-6 cell line (4). Thus, OHF may have anti-resorptive effects in vivo, although this remains to be explored in detail.

In conclusion, we demonstrate that androgens inhibit OPG production by several osteoblastic lineage cells: the transformed and AR-transfected hFOB/AR-6 cells, primary non-transfected MSC cells, and murine bone marrow stromal ST-2 cells. Since estrogen has been shown to stimulate OPG production, the finding that androgens inhibit OPG levels may, in part, explain why they are less potent than estrogens in decreasing bone resorption, even in men (7-9). Future studies assessing the differential regulation of OPG production by estrogens vs androgens may provide additional insight into the mechanism(s) whereby the two sex steroids have somewhat different effects on bone resorption.

\section{Acknowledgements}

We thank M J Schroeder, B Ngo, M Kauss and S Fischer for their technical assistance, and Dr B L Riggs for his comments. This study was supported by grant Ho 1875/2-1 from Deutsche Forschungsgemeinschaft and 10-1697-Ho1 from Deutsche Krebshilfe (to LCH) and grant AG-04875 from the National Institutes of Health (to SK).

\section{References}

1 Oursler MJ, Pederson L, Fitzpatrick L, Riggs BL \& Spelsberg TC. Human giant cell tumors of the bone (osteoclastomas) are estrogen target cells. PNAS 199491 5227-5231.

2 Pederson L, Kremer M, Judd J, Pascoe D, Spelsberg T, Riggs BL et al. Androgens regulate bone resorption activity of isolated osteoclasts in vitro. PNAS 199996 505-510.

3 Bellido T, Jilka RL, Boyce BF, Girasole G, Broxmeyer H, Dalrymple SA et al. Regulation of interleukin-6, osteoclastogenesis, bone mass by androgens. The role of the androgen receptor. Journal of Clinical Investigation $1995952886-2895$.

4 Hofbauer LC, Ten RM \& Khosla S. The anti-androgen hydroxyflutamide and androgens inhibit interleukin- 6 production by an androgen-responsive human osteoblastic cell line. Journal of Bone and Mineral Research 199914 1330-1337.
5 Jilka RL, Hangoc G, Girasole G, Passeri G, Williams DC, Abrams JS et al. Increased osteoclast development after estrogen loss; mediation by interleukin-6. Science 1992257 88-91.

6 Kassem M, Harris SA, Spelsberg TC \& Riggs BL. Estrogen inhibits interleukin-6 production and gene expression in a human osteoblastic lineage cell line with high levels of estrogen receptors. Journal of Bone and Mineral Research 199611 193-199.

7 Carani C, Simoni M, Faustini-Fustini M, Serpente S, Korach KS \& Simpson ER. Effect of testosterone and estradiol in a man with aromatase deficiency. New England Journal of Medicine 1997337 91-95.

8 Smith EP, Boyd J, Frank GR, Takahashi H, Cohen RM, Specker B et al. Estrogen resistance caused by a mutation in the estrogenreceptor gene in a man. New England Journal of Medicine 1994 331 1056-1061.

9 Falahati-Nini A, Riggs BL, Atkinson EJ, O’Fallon WM, Eastell R \& Khosla S. Relative contributions of testosterone and estrogen in regulating bone resorption and formation in normal elderly men. Journal of Clinical Investigation 2000106 1553-1560.

10 Lacey DL, Timms E, Tan H-L, Kelley MJ, Dunstan CR, Burgess T et al. Osteoprotegerin (OPG) ligand is a cytokine that regulates osteoclast differentiation and activation. Cell 199893 165-176.

11 Kong Y-Y, Feige U, Sarosi I, Bolon B, Tafuri A, Morony S et al. Activated $\mathrm{T}$ cells regulate bone loss and joint destruction in adjuvant arthritis through osteoprotegerin ligand. Nature $1999 \mathbf{4 0 2}$ 304-309.

12 Simonet WS, Lacey DL, Dunstan CR, Kelley M, Chang M-S, Lüthy $\mathrm{R}$ et al. Osteoprotegerin: a novel secreted protein involved in the regulation of bone density. Cell 199789 309-319.

13 Teitelbaum SL. Bone resorption by osteoclasts. Science 2000289 1504-1508.

14 Hofbauer LC, Khosla S, Dunstan CR, Lacey DL, Spelsberg TC \& Riggs BL. Estrogen stimulates gene expression and protein production of osteoprotegerin in human osteoblastic cells. Endocrinology $19991404367-4370$.

15 Saika M, Inoue D, Kido S \& Matsumoto T. 17ß-Estradiol stimulates expression of osteoprotegerin by a mouse stromal cell line, ST-2, via estrogen receptor- $\alpha$. Endocrinology $2001 \mathbf{1 4 2}$ 2205-2212.

16 Hofbauer LC, Hicok KC, Schroeder MJ, Harris SA, Robinson JA \& Khosla S. Development and characterization of a conditionally immortalized human osteoblastic cell line stably transfected with the human androgen receptor gene. Journal of Cellular Biochemistry $199766442-451$.

17 Pittenger MF, Mackay AM, Beck SC, Jaiswal RK, Douglas R, Mosca JD et al. Multilineage potential of adult human mesenchymal stem cells. Science $1999 \mathbf{2 8 4} 143-147$.

18 Harris SA, Enger RJ, Riggs BL \& Spelsberg TC. Development and characterization of a conditionally immortalized human fetal osteoblastic cell line. Journal of Bone and Mineral Research 1995 $10178-186$.

19 Hofbauer LC, Gori F, Riggs BL, Lacey DL, Dunstan CR, Spelsberg TC et al. Stimulation of osteoprotegerin ligand and inhibition of osteoprotegerin production by glucocorticoids in human osteoblastic lineage cells: potential paracrine mechanisms of glucocorticoid-induced osteoporosis. Endocrinology $19991404382-$ 4389.

20 Khosla S, Atkinson EJ, Dunstan CR \& O'Fallon WM. Effect of estrogen versus testosterone on circulating osteoprotegerin levels in normal elderly men. Journal of Clinical Endocrinology and Metabolism 200287 1550-1554.

21 Khosla S, Arrighi HM, Melton LJ III, Atkinson EJ, O'Fallon WM, Dunstan CR et al. Correlates of osteoprotegerin levels in women and men. Osteoporosis International 2002 (In Press).

Received 6 February 2002

Accepted 15 April 2002 